\title{
Water regimentation in the Pontine Plain between Astura and Fogliano in the dynamics of ancient population
}

The stretch of coast between Astura and Fogliano is characterized by a particular geomorphological situation linked to several difficulties in the drainage of the waters that have always generated marshes. In this contribution will be analysed the settlement and development dynamics of this particular territory from an archaeological point of view basing on the bibliographic and archive data, the survey and the photointerpretation. Considering the significant modifications that the territory has undergone because of the numerous reclamations, a reconstructions of the ancient ideography is also here proposed.

\section{Pontine Plain: geomorphology and water regimentation}

The stretch of coast between Torre Astura and Fogliano lake is nowadays a large inlet with a low and sandy coastline characterized by the aeolian dune system. This territory belongs to the widest area known as Pontine Plain or Pontine Swamps (fig. 1), bounded on the East by the Lepini mountains and in the northern side by the Ausoni'. It is characterized by clays, silts and peats, related to swamps, filled until the historical era (fig. 2). The substratum of the Pontine Plain ${ }^{2}$ contains aquifer fed by the mountains system, the water flows through Mesozoic limestone rocks, determining some water resurgences (as the Ninfa lake, for example). The slight

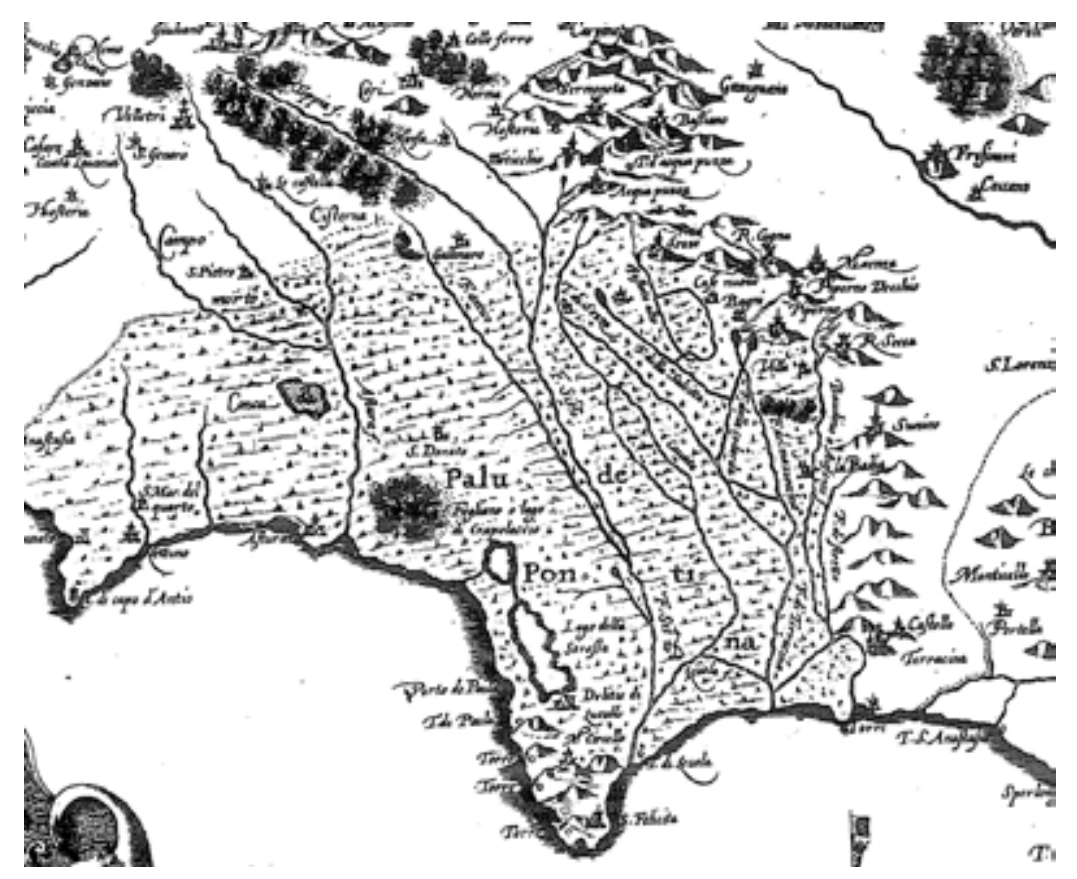

1 Traina 1988, 49-75.

2 Boni et al. 1980, 204-247; Cerreti 2003, 1-26. See also Caciorgna 2016 and cited bibliography. 


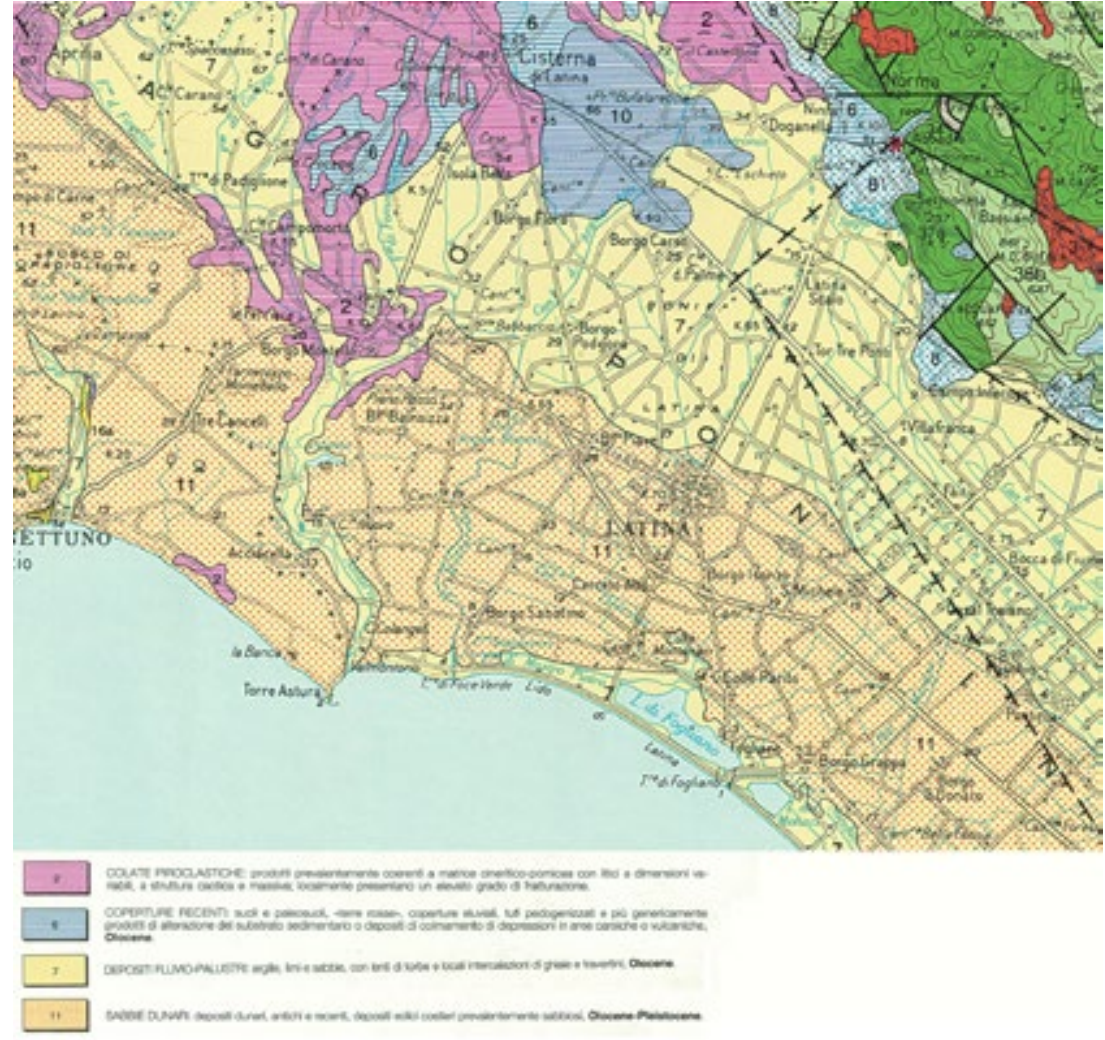

Fig. 2. Lithographicstructural model edited by Regione Lazio, excerpt underground slope, the lower level of internal soils compared to external ones, the subsidence of few centimetres every year, the coastal dune, the obstruction of the mouths of rivers and ditches and the lack of a general and complete drainage system over the centuries have always slowed down flow of the waters generating wide swamps. The clastic material transported from the mountains trough the rivers determined the filling of the coastal lacustrine pond, while, at the same time, the development of the geological formation so-called 'Duna Rossa', along a strip parallel to the coastline. From a pedological point of view ${ }^{3}$, nearby the ancient dune is present a particular and rare kind of soil, named Planosol, a whitish eluvial layer with low clay content, superimposed on an illuvial layer with higher clay content. It is characterized by a sandy soil on the surface with water stagnation after the rains because of a clay layer underneath. The Planasols developed in the coastal area of Latina and Rome is referred to the Middle-Upper Pleistocene with significant contrast between the rainy season and the dry one. This kind of soil is really rare not only in Italy, but in all the Europe and it is associated to the Albic Luvisols, characterized by a less abrupt change between the eluvial and illuvial layers.

The modern Pontine Plain is certainly the result of the geomorphological and hydrographical conditions of its territory, but also of all the anthropic actions of reclaiming over the centuries, with the purpose to make it habitable and cultivable. It is not easy to define chronologically the first reclamation, although the tradition handed down by Plinius about the Pontine Plain remind that the area defined palus Pomptina, so in its sense of marsh area, was related to even 23 cities $^{4}$. Such a populous area suggests a care of the territory connected to regimentation works, already certainly implemented for some time. As we shall see later, the work methodology and the ditch chosen as water collectors were, over the centuries, more or less the same. The first pontiff to undertake an ambitious project for the Pontine Plain was Leo X (1513-1521), the relative project was realized by

3 Arnoldus et al. 2009, 18-20 and attached cd.

4 Plin, Nat. Hist. III, 59. 
Leonardo Da Vinci. The map ${ }^{5}$ shows that, starting from the Via Appia, the water courses are all conveyed into the Rio Martino and the Badino, characterized graphically by a double line, water runoff lines already used in roman times and in all subsequent reclamation. After the death of Leo X, Pope Sixtus V (1585-1590) and then Pius VI (1755-1799) resumed activities. The main element of the latter's work was the Linea Pio, canal parallel to the Via Appia and navigable up to Terracina. It constitutes the re-digging of the so called Decennovio ${ }^{6}$, known by ancient sources ${ }^{7}$, a navigable canal used when the marshy conditions did not allow the use of the road. In 1861 was instituted the 'Consorzio della Bonificazione Pontina' and in 1900 the Parliament approved the law on the reclamation of the wetlands, which states that the reclamation works should be carried out with the competition of the State. After the First World War the pontine marshes were divided into two areas (Marchi project), one on the left of the Sisto river, belonging to the existing 'Consorzio della Bonificazione Pontina', and the other on the right of the Sisto river, belonging to the new Consorzio di Bonifica di Piscinara ${ }^{8}$. The Marchi project, then put into practice with the work of the 30s, involved the division of waters into:

- high waters: surface waters from the mountains basins, conveyed through special channels into the so called 'Canale delle Acque Alte'

- medium waters: coming from springs or streams along the foothill and the medium altitude area, conveyed into the 'Canale delle Acque Medie'

- low waters: stagnant, result of precipitation, infiltration and resurgences, conveyed in the 'Canale delle Acque Basse'.

Furthermore mechanical drainage of lands that could not naturally be drained was provided, using water pumps. The reclamation was named 'Integrale' (fig. 3) because, in addition to the hydraulic reclamation, it was also included the sanitary and agricultural reclamation with the agrarian division and the insertion of the settlers? ${ }^{9}$ This digression on the history of reclamation, especially the most recent, seems to detach from the target of this contribution, but in reality provides
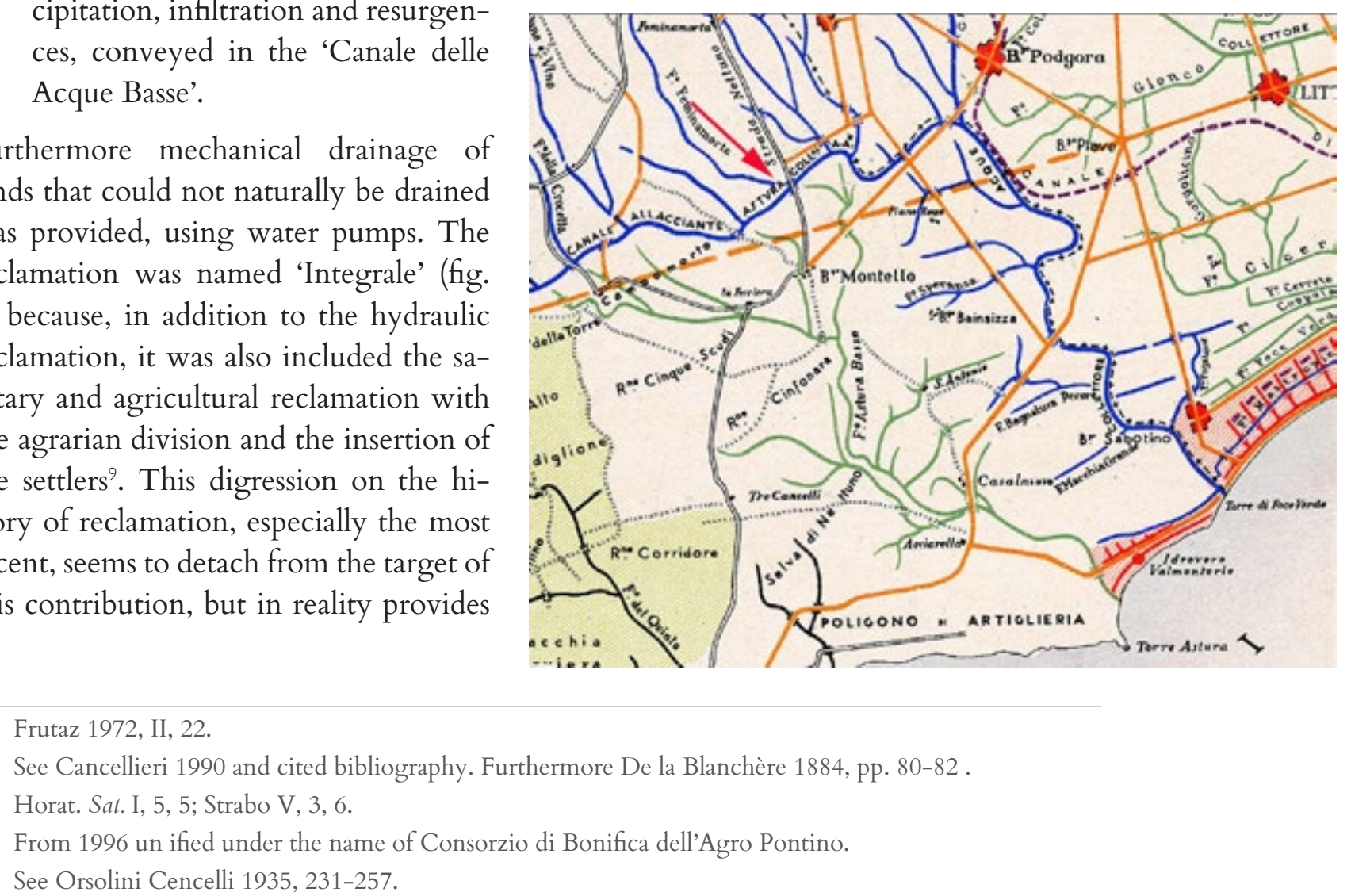
significant data for the reading and understanding the development of this territory from an archaeological point of view.

Fig. 4. Hypothetical reconstruction of the dune and lacustrine system with prehistoric evidences The points and the areas in red indicate the finds of lithic industry attributable to Pontiniano industry highlighted during the survey by the author. The arrow shows the toponym Prato di Coppola, where is appreciable the difference in height of the internal dune system (rendering L. Ebanista, base IGM 1:25.0000, serie 25/V)

\section{The coast between Astura and Fogliano}

Focusing now on the area covered by this research, along the coastline is evident the presence of a system of the coastal lakes. The modern basins (from North-West Fogliano, Monaci, Caprolace and Paola or Sorresca), redefined in terms of shape and size from the modern banks, are the results of ancient elongated shape ponds parallel to the coast, formed due to the difficulty of the waters to flow out the sea trough the barrier formed by the dunes (fig. 3). The possibility of undertaking pollen analysis by means of coring in the coastal ponds has been excluded because in first 10 meters deep just the environmental evolution of the last three centuries would be possible to check. So the data could be related to the most recent reclamations which buried the pond, already subjected both to the geological subsidence and the constipation of recent sediments ${ }^{10}$.

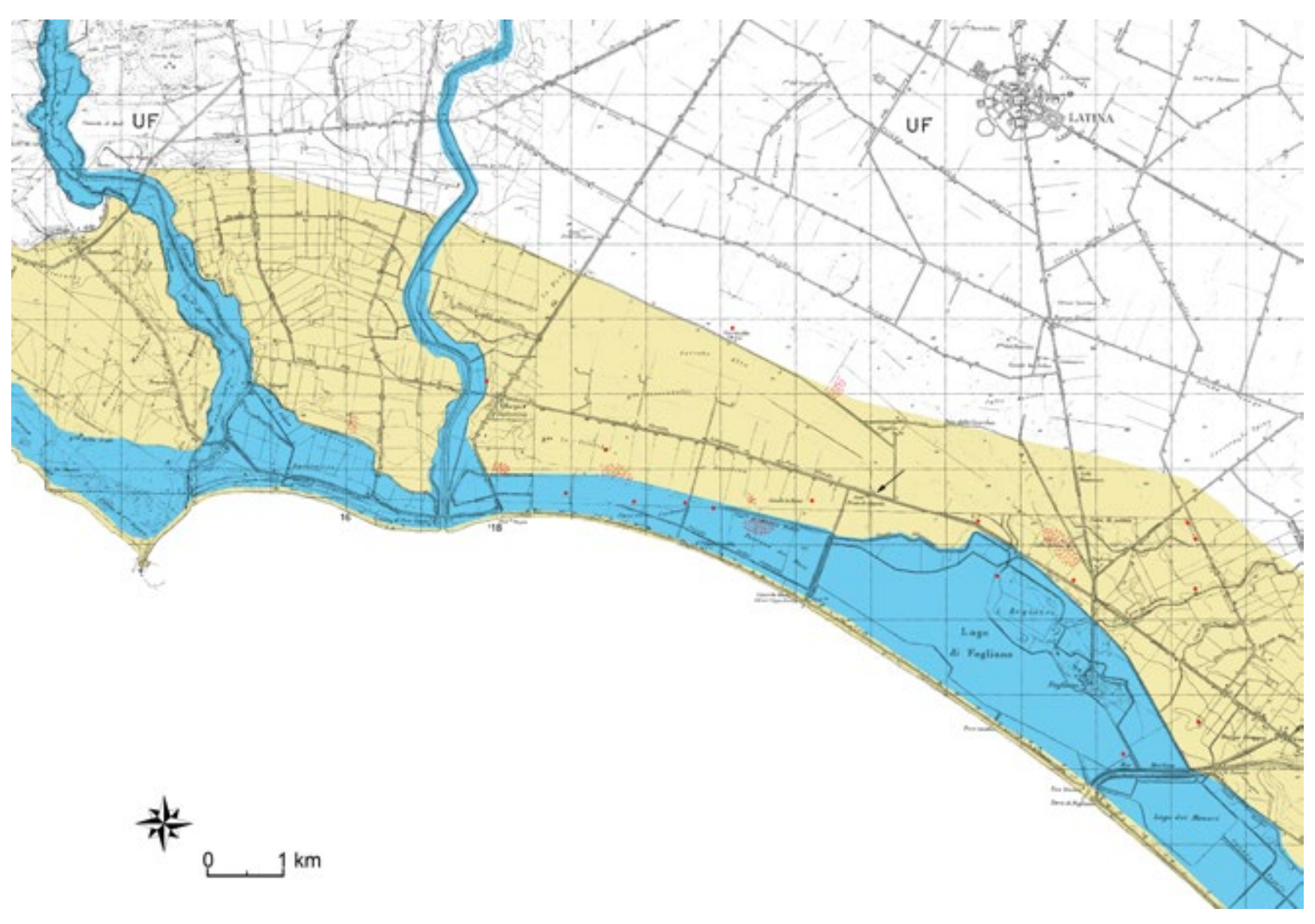

10 Di Filippo, Toro 1980. 


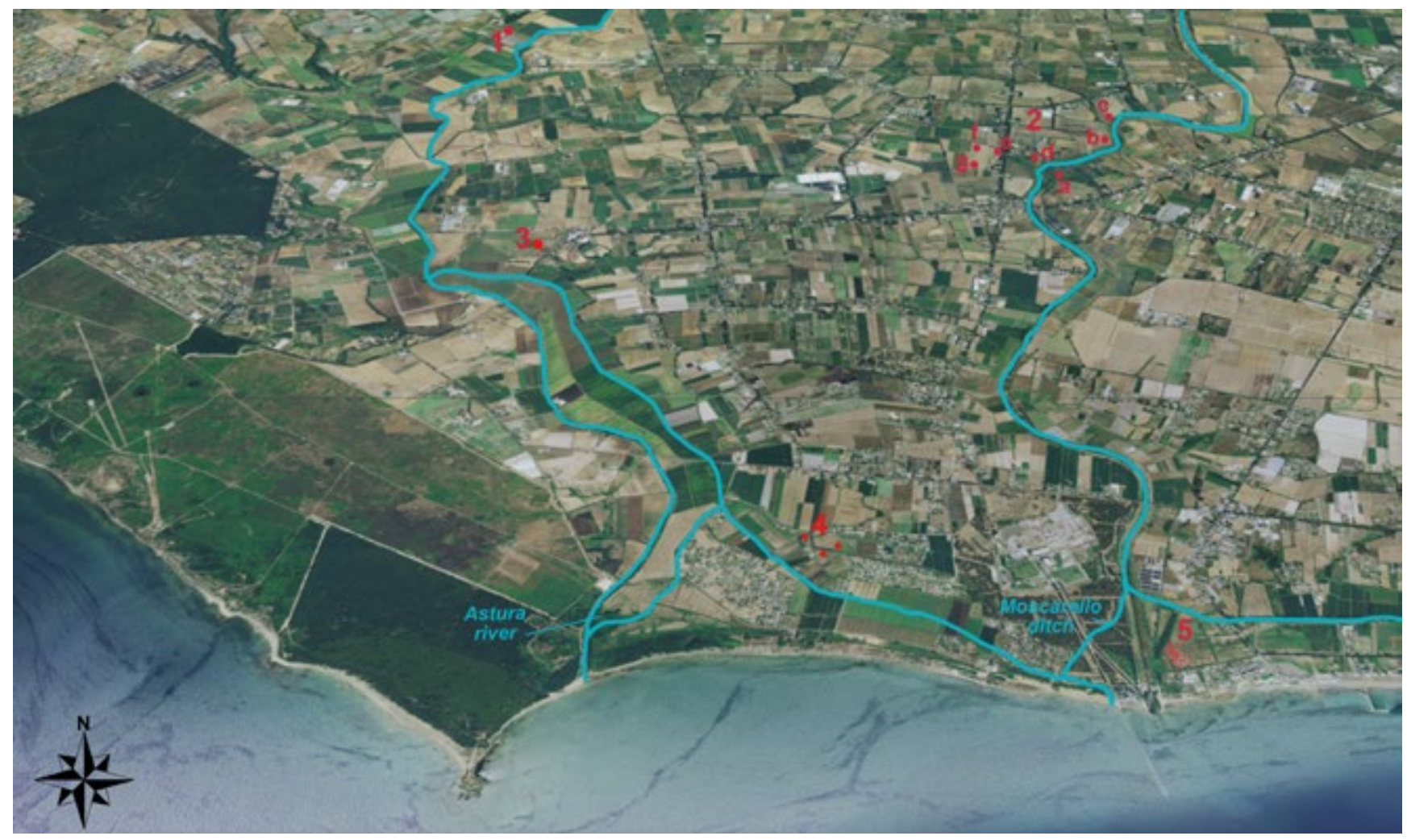

It is not easy to define the morphology of these coastal ponds across the centuries because of their continuous natural evolution and of all the works of reclamations occurred over the centuries, but it is certain that the aspects of the territory was not so different at the beginning of the last century, as visible in some historical photos" of the 30s. The great amount of malacofauna (in particular Cerithium vulgatum vulgatum), highlighted during my surveys ${ }^{12}$ in the Foceverde area (for precise localization see fig. 5, n. 5), testifies the presence of swamps, even in fairly recent times.

The internal dune system was located North of these modern lakes, corresponding to the old ponds, but today it is not appreciable due to the heavy agricultural excavations (mainly installation of vines) from the 60s of the last century that lowered the planking level several meters. To the north of the Fogliano lake, in toponym Prato di Coppola, a difference Fig. 5. Original courses of Astura and Moscarello (in light blue) based on photointerpretation data and historical maps (base from Geoportale Nazionale http:// www.pcn.minambiente.it/viewer3D/). In red the prehistoric and protohistoric finding locations mentioned in the text with the relative number (rendering $L$. Ebanista) in height that is still noticeable today (especially along the modern via del Lido), testifies the presence of the ancient dune in this stretch located about $1.5 \mathrm{~km}$ from the modern coastline (fig. 4).

Obviously, the hydrography of the Pontine Plain influenced the dynamics of peopling and the installation of the infrastructure systems. Among the latter, for example, the preference for the waterways instead of the classic roads is closely connected to a territory in continuous evolution in relation to times and seasons. The cultural aspect of transhumance

11 AFCB, 334, 337.

12 Edited in Ebanista 2017; specifically for the malacofauna see 15, 61. 
from the mountains to the plain continued uninterruptedly until the last reclamation. In a fairly recent era, the so-called 'lestre', huts with conical roof made of straw and wood, were used by shepherds and peasants who seasonally, usually from October to June, occupied the plain area for their rural activities, retreating to the mountains in the winter period when the abundant rains determined the extension of the marshes ${ }^{13}$. Therefore the cabotage was a system certainly exploited in the coastal ponds from antiquity to a fairly recent age.

The specific stretch of the southern Latium coast discussed in this paper, is crossed by three watercourse of different nature, which had a significant impact on the dynamics of peopling: from North-West the Astura river, the Moscarello ditch and the Rio Martino, an artificial canal. In this paper the coastal ponds and the three waterways are analysed, with reference to their function and to the anthropic deviations and alteration they have undergone over the centuries. The research is based on archaeological data collected during archaeological surveys undertaken by the writer ${ }^{14}$, from the bibliography ${ }^{15}$, the archive data and the aerial photo interpretation.

\section{Prehistoric and protostoric period}

It is conceivable that the internal dune was inhabited during the Paleolithic, as evidenced by the lithic findings attributable to the 'Pontiniano' industry ${ }^{16}$ (fig. 4). All these materials, now mainly concentrated in the most depressed area interpretable as the ancient ponds, are surely slipped down from the top of the internal dune, also considering the significant earth movements, at first determined by the reclamations over the centuries, then by the agricultural work ${ }^{17}$. Already from the Lower Paleolithic the waterways were aggregation elements in the Pontine plain as demonstrated by the discoveries in toponym Quarto delle Cinfonare $^{18}$ on the west side of Astura river (fig. 5, n.1). The materials found on the east and west bank of the Moscarello ditcht, in the summit area of the ancient dune, are instead dated to the Middle and Upper Paleolithic ${ }^{19}$ (fig. 5, nn. 2a-g).

During the Protohistoric age, settlement are attested along the waterways, used as communication routes between the coast and the most immediately inland areas ${ }^{20}$. The impor-

13 Cipolla 2013, 26-27.

$14 \quad$ Ebanista 2011 and Ebanista 2017.

15 See Alessandri 2007, 25-34.

16 Zei 1988, 83-94 and Ebanista 2017, 15, 35-36.

17 Ebanista 2017, 35-36.

18 La Rosa et al. 1992; La Rosa et al. 1996; Peretto et al. 1997; La Rosa 2006. Edited also in Ebanista 2017, pp. 35-36, 72, n. 125S.

19 La Rosa 1984a, 9-27; La Rosa 1984b, 221-226. Edited also in Ebanista 2017, pp. 35-36, 69, n. 87Sa-g.

20 The sites identified by Piccarreta 1977 are reviewed without substantial news in Tol 2012, 38-49. In Ebanista 2017, the surveys undertaken by Piccarreta are replicated for the area under the provincial administration of Latina (in tab. $\mathrm{V}$ in appendix a comparative model of the researches). 
tance of the Astura river and the Moscarello ditch is attested by the findings from Casale Nuovo, datable to the Final Bronze age ${ }^{21}$ (fig. 5, n. 3), and from La Fibbia, datable to the early Iron Age (fig. 5, n. 4) 22 .

\section{Pre Roman and Roman period}

It is right to tackle the question of these two waterway together because, as we will see, their connection is rather tight in the dynamics of water regimentation of the Pontine Plain, both before and after the last reclamation. Astura was originated from numerous

Fig. 6. Settlements and infrastructures

in Roman and pre Roman times (rendering L. Ebanista, base IGM 1:25.0000, serie

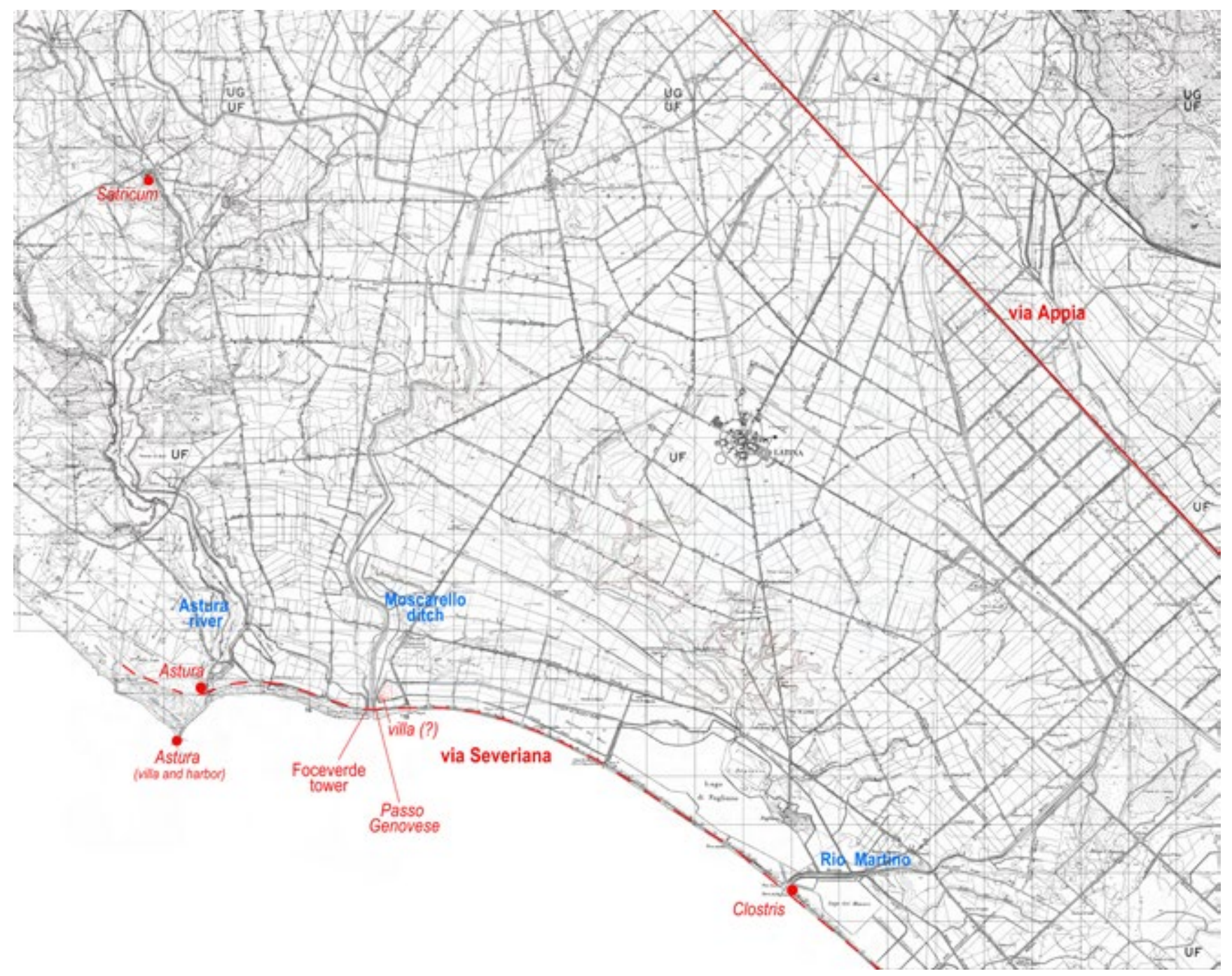

21 Angle, Zarattini 1987, 250-252; Guidi 1989, p. 28; Angle et al. 1992, tab. VIII-IX, n. 30; Belardelli, Pascucci 1996, 52, n. 11, tab. III, 61-63; Giardino 2006, 25-48; Alessandri 2007, 108-109. Edited in Ebanista 2017, 66 n. 63S.

22 Piccarreta 1977, 90 n. 156; Cardarelli et al. 1980, 91-103 n. 324; Belardelli, Pascucci 1996, 52 n. 12; Alessandri 2007, 108-113. Edited in Ebanista, 62-63 n. 22-24S; see furthermore 62, 64 nn. 13-14-17-41-42S and previous bibliography. 
rivers that descended from the southern slope of Albani mountains. Nowadays its flow is significantly reduced as, following the last reclamation its waters are diverted through a 'Collettore' (a connecting waterline) into the so called 'Canale delle Acque Alte' (fig. 3). Still in 1935 the flow of Astura was abundant, as shown by some historical photos ${ }^{23}$. In ancient times the river was navigable by towing ${ }^{24}$. Before the building of the villa and its harbor at Astura ${ }^{25}$ (fig. 6), the mouth of the river was the fluvial harbour of the ancient city of Satricum ${ }^{26}$, used until the city was gradually abandoned and probably still in the I century BC, when the Astura villa was probably not built yet, as demonstrated by Cicero's letters ${ }^{27}$. F. Piccarreta assumed, basing on the materials highlighted along the course of the Astura river (pottery related to archaic age, generally datable at the V-IV century BC) the existence of an archaic town of Astura, however not preserved ${ }^{28}$.

The mouths of rivers and ditches take on an important significance for the settlement during the late Republican and the Imperial age. Specifically in this area, the archaeological surveys conducted by the writer show that coastal settlements in this stretch of coast maintain continuity up to the middle and late Imperial age, instead a clear rarefaction of the presences from the average and late Republican age is highlighted in the whole area behind the second dune system ${ }^{29}$. The construction of the Via Appia in 312 BC certainly caused the shifting of the communication lines into a more internal area. The coast remained vital in the access points to the hinterland, therefore to the mouths of ditches and rivers in relation to the possibility of reaching the more internal centres.

For the stretch of coast covered by this research, in addition to the already famous villa at Torre Astura ${ }^{30}$, another one is conceivable at the modern mouth of the Moscarello (fig. 6) testified by a dense dispersion of pottery and architectural material datable from the middle Republican age to the imperial age ${ }^{31}$. The structures were partially destroyed by excavation work of the Canale delle Acque Alte in 1935, which will be discussed later in this paper.

A porticoed villa is situated at the mouth of Rio Martino, South of the Fogliano lake (fig. 6), and can be interpreted as Clostris, one of the Via Severiana stationes ${ }^{32}$. In this case the continuity of the settlement is attested by archaeological data at least until IV century

23 AFCB, 1433. The picture shows the river that forms a waterfall upstream Le Ferriere.

24 Piccarreta 1977, 18-21.

25 Ebanista 2020.

26 Gnade 2017, 74-84, furthermore Liv. XXVIII, 11,1-3.

27 Cic. Att. XII, 19, 1.

28 Piccarreta 1977, 18-21, n. 1.

29 Ebanista 2017, 32, 37-40. On the broader topic see Jaia 2017, 209-221.

30 For a detailed analysis of the structures Piccarreta 1977 and cited bibliography.

31 Ebanista 2017, 61 n. 8S.

32 For the attribution hypothesis of the road statio see Ebanista 2017, 22-23, 32-33, 50-56 and cited bibliography. 
$\mathrm{AD}^{33}$. The building of the just mentioned Via Severiana ${ }^{34}$, which is placed chronologically during the Empire of Settimio Severo and Caracalla, is the proof of the vitality of this stretch of coast. It was surely built connecting a series of already existing coastal paths, useful for the attested settlement and through the ascent of rivers and canals gave access to internal centers. Already two centuries earlier a projects for this stretch of coast was undertaken although never completed: a ditch conceived by Nero in order to connect the mouth of the Tiber with the Averno lake with the aim of wrapping the waters into an internal channel, always navigable ${ }^{35}$. Certainly, even in this case, existing ditch were connected. The eighteenth-century bridge named 'Passo Genovese' at Foceverde (fig. 6) is the proof of the existence of a canal parallel to the coastline, still three centuries ago. The area at the mouth of Moscarello must still have been a landing place, as recalled by its toponym, when the Genoese in the XIV century used the wood of the forests of the Tyrrhenian coast in the section between Anzio and Terracina, in the ambit of the domination of Genoa on the coastal city of Terracina (18 May 1346 - 31 December 1367) at the southern border of the State of the Church with the Kingdom of Naples ${ }^{36}$.

33 Ebanista 2017, 50-56, n. 11F.

Fig. 7. Mosaic of S.A.R.A. flight, unknown year, 25 , 2130 on the right and RAF flight, 1944, 29, 4089 on the left (rendering $L$. Ebanista)

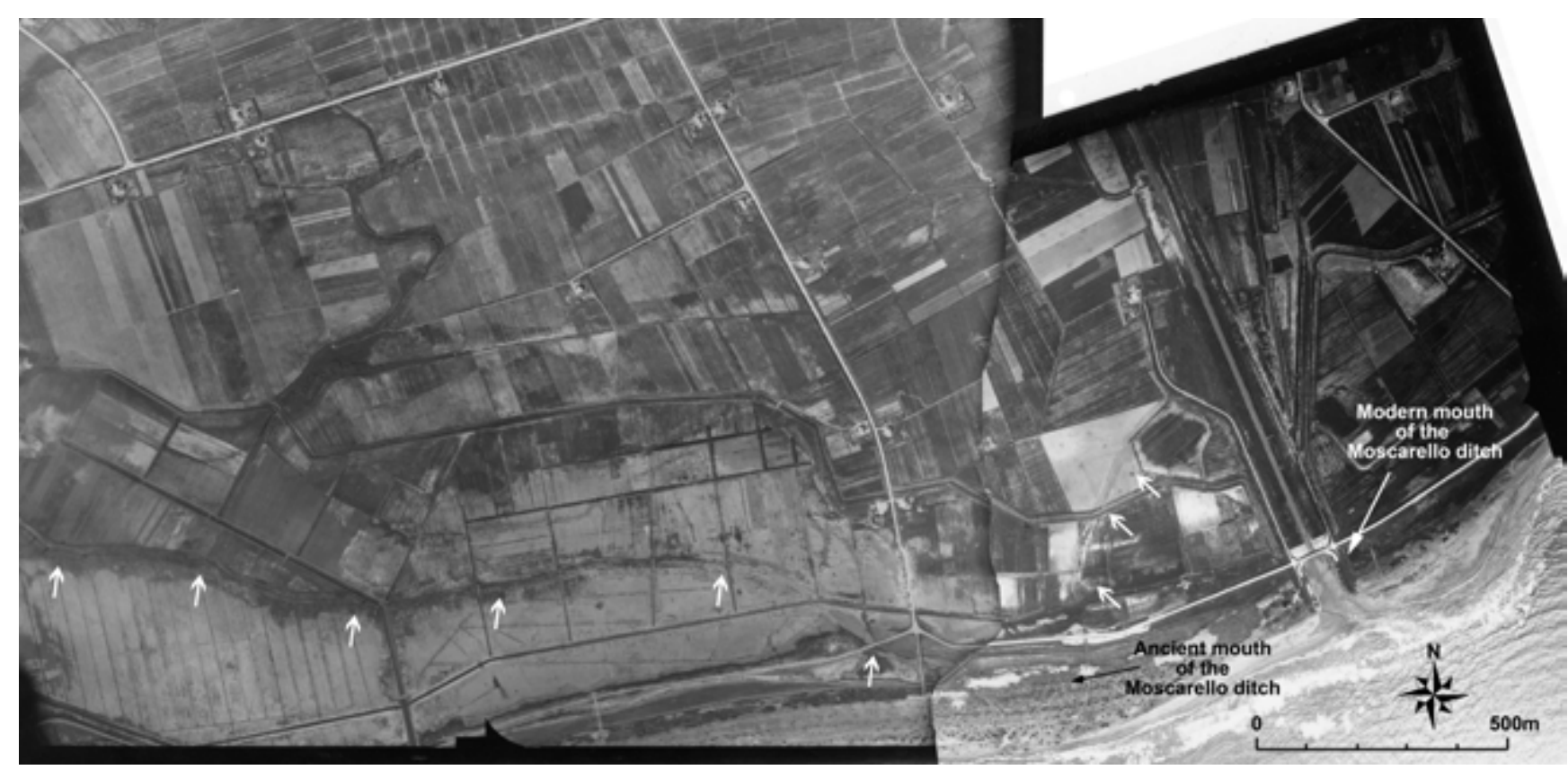

For the bibliography see the paragraph no. 6 "Rio Martino canal".

Quilici 1998.

36 See Caciorgna 2008. 


\section{Moscarello original mouth}

The examination of the aerial photography and the historical cartography allow the reconstruction of the original mouth of the Moscarello ditch before the water regimentation of the 30s of the last century. The reclamation project involved the re-excavation of the ditch according to the technique of a particular kind of artificial canal called 'cunettone' ${ }^{37}$ : it is a kind of duct with a sufficiently regular artificial bed excavated (in this case with a trapezoidal section and stepped sides), protected on the bottom with stone tied with mortar or other material not erodible by the current. The paving of the bottom is clearly visible in historical photos taken during the works in $1935^{38}$. Furthermore the canal was rectified at the mouth in order to flow more easily, and today leads immediately East of Foceverde tower (fig. 5).

Fig. 8. Excerpt from L. Canina map, 1843 (Archivio Storico Capitolino, Tomassettifund, n. 198). Courtesy of Sovrintendenza - Archivio di Stato Capitolino (sign: TOM 198)
The mosaic of two aerial photos ${ }^{39}$ allows a clear reading of the tracks of an old ditch, approximately parallel to the coast (fig. 7), which starts from Astura river towards the sea from West to East ${ }^{40}$ and of the ancient mouth of Moscarello ditch which turned westward ${ }^{41}$. Although the least legible part of the traces from is the ancient mouth that is in the junction between the two aerial photos, the ancient hydrographical trend is also confirmed by a map by Luigi Canina of $1843^{42}$ (fig. 8 ). The map shows Moscarello ditch that, few hundred meters from the coastline, is divided into two lines, one towards West

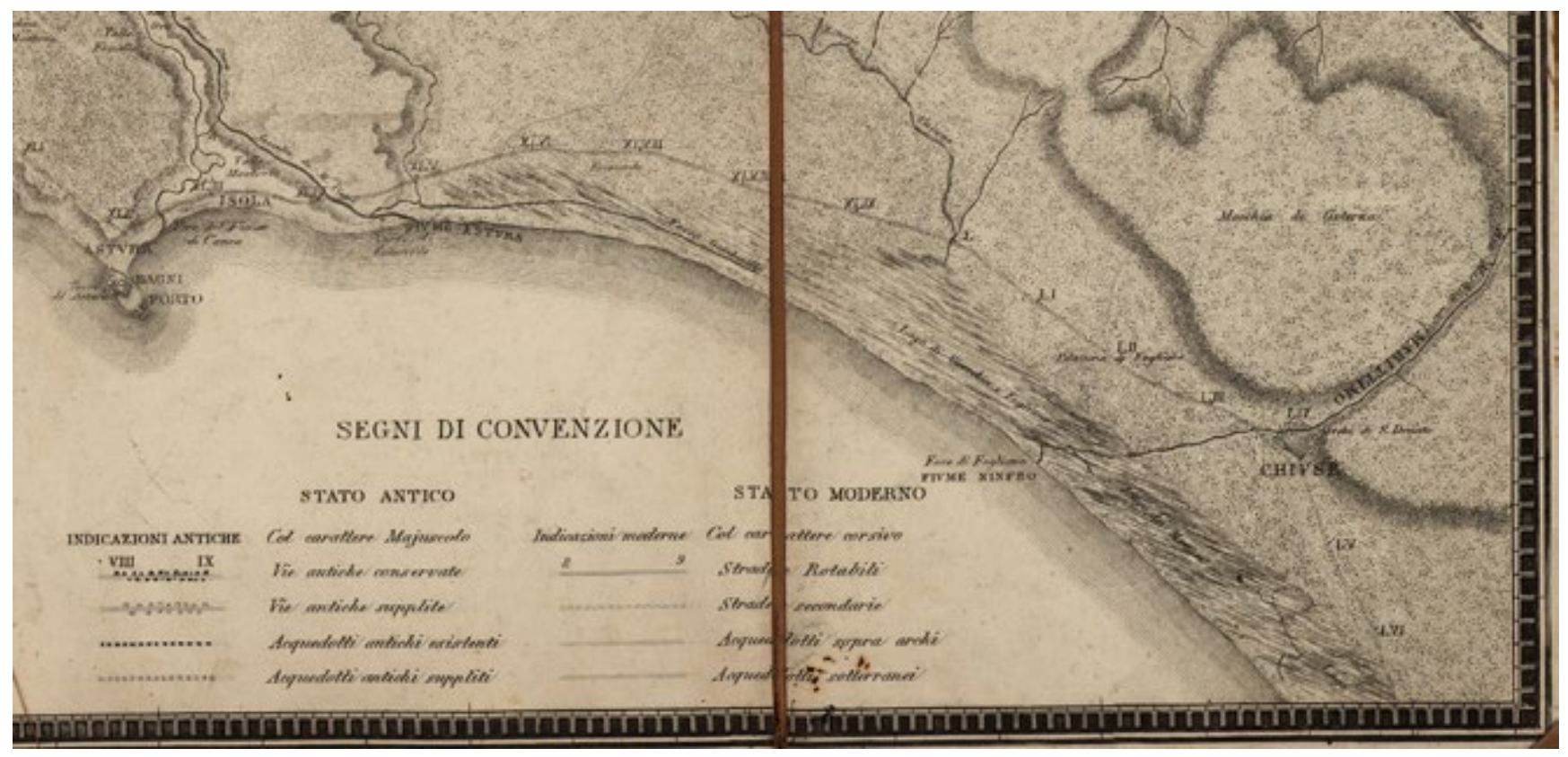

37 See Ligato 2003, 62-64.

38 AFCB, 1558 (13.10.1935).

39 AFN: S.A.R.A. flight, unknown year, 25, 2130 and RAF flight, 1944, 29, 4089.

40 Visible in RAF flight, 1944, 29, 4089.1

41 Visible in S.A.R.A. flight, unknown year, 25, 2130.

42 ASC, Tomassetti fund, n. 198, L. Canina, 1843. 
which flows into the river "Stura detto Fossella di Mastro Pietro" and the other towards East, called "Fosso Giordanello" which flows, after about 6 km, into Fogliano lake. The denomination "Mastro Pietro", that has been lost for the watercourse West of the mouth of Moscarello, is preserved instead in the modern toponym to the East. The ditch named "Giordanello" in Canina's map, with good reason, could be identified with the modern Mastro Pietro ditch. Therefore, in ancient times, Moscarello did not flow into the sea in rectilinear way as today, but it was divided into two water courses parallel to the coast, certainly to counteract the difficulty of water flow caused by the presence of the dune.

\section{Rio Martino canal}

The Rio Martino traces the course of a roman canal that could probably be identified with the reclamation works of Cornelio Cethego undertaken during the II century BC and narrated by Livy. ${ }^{43}$ Its importance within the water regimentation of the Pontine region is evidenced by its inclusion in the reclamation projects that have taken place over the centuries: during the pontificate of Leo X (1513-1521) ${ }^{44}$ and of Innocent XI (1676-1689) ${ }^{45}$. The function of the Rio Martino canal is also central during the Pius VI (1755-1799) reclamations ${ }^{46}$. The ancient riverbed has been reused during of reclamation of the last century and its course is now the 'Canale delle Acque Medie' (fig. 3) ${ }^{47}$. The general executive project of the Acque Medie collector was presented on 04.09.1929 and approved with Ministerial Decree on 26.09.1929 (n. 5854/7091) ${ }^{48}$, the text of the project reports the following: "Utilizzazione dell'alveo del rio Martino già da secoli aperto [...] piccoli movimenti di terra di adattamento e, più che altro, di espurgo e pulizia del fondo e delle scarpate [...]". The stretch of the intervention, up to the sea, was $8859 \mathrm{~m}$ long and included numerous level drops, the banks of the canal were covered to reinforce its side, at the same time as the embankment works of the lakes ${ }^{49}$. Today Rio Martino is the canal-port of the city of Latina and its accommodation works ended in 2017, in the context of a redevelopment project which significantly modified the conformation of its mouth. These more recent works, combined with the concrete and limestone embankments of the 30s of the last century make it impossible to read any ancient remains, seen by Egidi ${ }^{50}$, but not seen by the writer even during reconnaissance prior to the recent renovation of the mouth' ${ }^{51}$. The 'rivo Martino' is already known by the Concordia act approved by Bonifacio VIII in 1299 which

43 Liv. Per, XLVI.

44 As testified by Pontine Marshes Map by Leonardo da Vinci (1513-1516), see Frutaz 1972, II, tab. 22.

45 Map by Cornelio Meyer attached to the draining project for the Pontine Marshes, see Frutaz 1972, II, tab. 159. The map also depicts the 'padiglione dove alloggiò Sisto V l'anno 1583'.

46 Frutaz 1972, I, 94-97; II, 201-207.

47 See Ebanista 2017, 25-28, 56 n. 12F and cited bibliography.

48 ASL, Consorzio di Bonifica di Piscinara, report lotti 59-60-61.

49 ASL, Consorzio di Bonifica di Latina, busta 102a, scheda 1237.

50 Egidi 1980, 123-125.

51 Ebanista 2017, 56 n. 12F. 


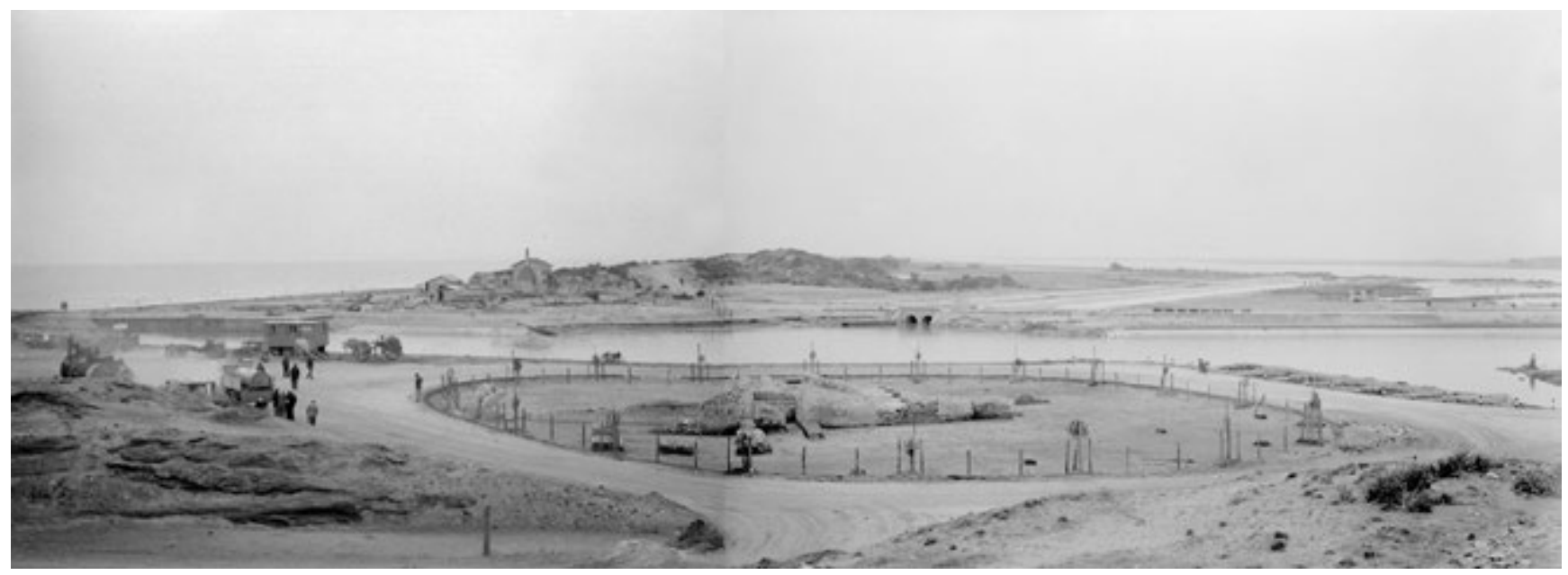

Fig. 9. Clostris remains at the mouth of the Rio Martino in two historical photos of 1934 (AFCB, nos. 1031-1032) resolved the dispute between Setini and Sermonetani originated from the regimentation activities of the inhabitants of Sermoneta who had diverted some streams forming marshes in the area of Sezze ${ }^{52}$. The area at the mouth of Rio Martino has always been connected to the toponym 'San Donato,53, in its variants of 'arcs' or 'walls'. Although, on the basis of the historical cartography ${ }^{54}$, it is conceivable that this toponym should be placed in a more internal place than this right on the coast, the area adjacent to the mouth of the Rio Martino was a nerve settlement centre. Here are located the remains of a porticoed villa (fig. 6) excavated at the end of 19th century by Elter ${ }^{55}$, seen by Thomas Ashby ${ }^{56}$ in 1905 and delimited and preserved during the reclamation works of the last century ${ }^{57}$ (fig. 9). The frequentation of the area is confirmed by the excavation data of the villa reported by Elter ${ }^{58}$ : since the I century AD by the presence of a stamped lead fistula: Silanae M(arci) $f\left(\right.$ iliae $^{59}$ and of some stamped bricks ${ }^{60}$ and it continues at least until the IV century when it can be dated the sepulchral inscribed slab of Kamenio ${ }^{6 !}$. The villa had at least two building phases attested by the archaeological data. It is conceivable that the area of the mouth, located in a strategic position, was populated following the reclamation of Cethego, if it is confirmed the insertion of Rio Martino excavation in these reclamation works. I will

52 Moroni 1854, 70.

53 On this topic, see Ebanista 2017, 26-28 and cited bibliography.

54 For the arguments and the cartographic references, see Ebanista 2011, 126 and Ebanista 2017, 25-28.

55 Elter 1884, 56-79.

56 Le Pera Buranelli 1994, 173-175.

57 AFCB, 1031-1032, anno 1934.Edited in Ebanista 2017, 50-56 n. 11F. In June 2012 a cleaning of the structures, which were invaded by vegetation, was carried out in order to realize a planimetry (fig. 41).

58 Edited in Elter 1884.

59 Elter 1884, 75-78; CILX, 8296.

60 Similar to CIL X, 8042,36d, 8042,36e and 8043,52.

61 Elter 1884, 56-79; ILS, 1264; CLE 654. Edited with photo in Ebanista 2017, 54-55. 


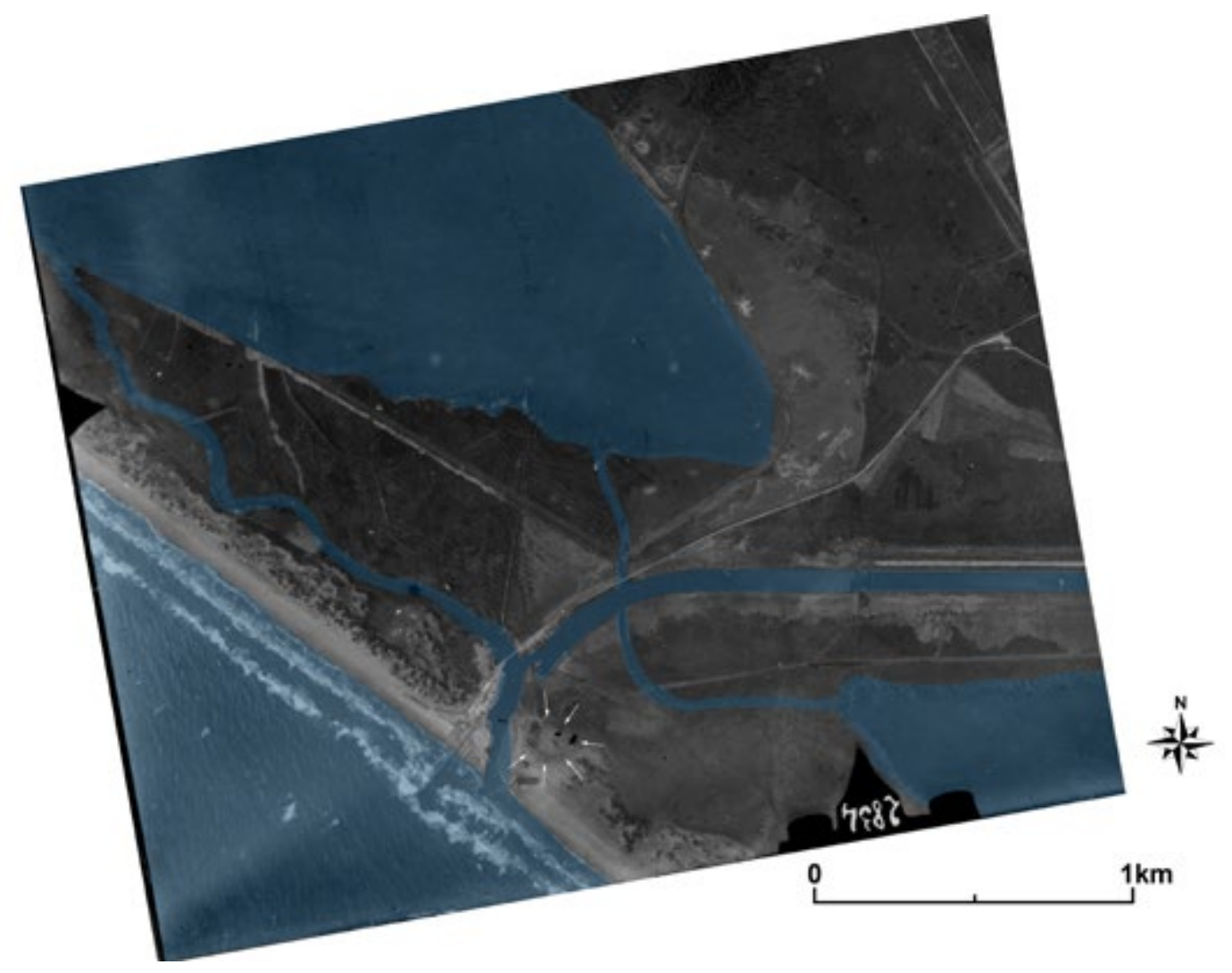

Fig. 10. The aerial photography (1933) shows the situation of the mouth of the Rio Martino prior to the complete construction of the embankments. The white arrows indicate the ridge occupied by the villa (rendering $L$. Ebanista)

not dwell here on the technical aspects of the buildings ${ }^{62}$, but rather on the villa position related to the hydrography of this portion of the coast.

The villa had been built in a place with evident difficulties related to the hydrographical situation, as also shown by the five foundation pillars in the East sector ${ }^{63}$, which probably had the function of raising a floor with problems of water rise, as would be confirmed by the fact that still today the groundwater is higher in this sector and a dense marsh vegetation grows rapidly. The choice of its position, despite the undeniable problems certainly related to its construction, is certainly not accidental.

An aerial photo of $1933^{64}$ (fig. 10) shows a situation prior to the complete construction of the banks of Fogliano and Monaci lakes; the works took place between 1932 and $1940^{65}$ even if the photographic documentation shows that the works had to be already completed in $1934^{66}$ for the Fogliano lake. In the aerial photo is clear that the villa is located on a small hill; along the waterway there were some islets formed where the rivers, the ditches or the

62 Edited in Ebanista 2017, 50-56 n. 11F. In June 2012 a cleaning of the structures, which were invaded by vegetation, was carried out in order to realize the planimetry (fig. 41).

63 Ebanista 2017, 52.

64 AFN, S.A.R.A. flight, 1933, 50, 2834.

65 ASL, Consorzio di Bonifica di Latina, busta 102a, scheda 1237.

66 AFCB, 829-830 (1932) and 1057-1058 (1934). 


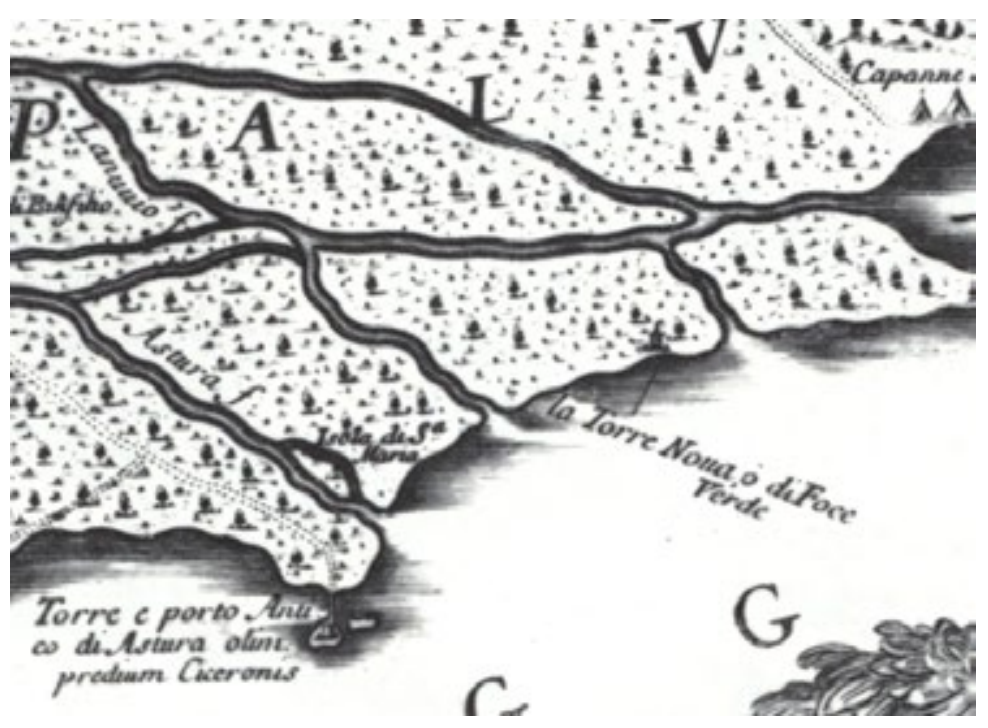

Fig. 11. Excerpt from G. F. Ametimap, 1693 (Frutaz 1972, II, tav. 177)

canals doubled close to small ridges which could not overcome due to the slight slope ${ }^{67}$. An example for this can be the 'Isola di S.a Maria' depicted in a map by Gian Filippo Ameti of $1693^{68}$ (fig. 11). Elter, in the description of the findings at the mouth of Rio Martino, refers to a 'piccola altura'69, providing information on the kind of landscape in this area. The aerial photo, which was taken when the works were halfway through, shows an intermediate situation: the Fogliano lake has banks well defined already in its north side, while in the south and east side it shows a natural situation, some irregularly shaped rivers connect the lakes and the Rio Martino, and the latter has a little defined mouth, just South of the villa, bypassing the hill on which it was located. The place where the buildings are located is certainly strategic and, not by chance, when at the beginning of the III century AD the Via Severiana ${ }^{70}$ was built, linking pre-existing roads, this place becomes the site of a statio viaria. The hypothesis that it could be Clostris, located, as known from the Tabula Peutingeriana, IX miles from Astura is based on the correct calculation of miles (the linear distance between the mouth of the Astura river and the buildings at Rio Martino is about $13.200 \mathrm{~m}$, distance compatible with the IX miles known from the Tabula) and on its toponym. I would like to exclude the hypothesis of Brandizzi Vittucci ${ }^{71}$, in fact seems to be unlikely that the stationes indicated in the Tabula do not coincide with inhabited centres, but with locations defined basing on specific features (as area for fairs or markets, for example). Returning to the question of the toponym, it seems that Clostris is referred to a system of locks, certainly present also in ancient period to regulate the water flow from the lakes to the Rio Martino and from the latter to the sea, and depicted in the Luigi Canina map (fig. 8). Furthermore these locks systems are mentioned in the Phaenippus inscription ${ }^{72}$ (second half of the I century $\mathrm{AD}$ ), discovered during Elter excavation at the end of the 19th century; the text refers to locks and substructures works [---opera c]ludentium et substruc[tiones---], made by one or more characters, perhaps imperial prosecutors. The locks, which regulated the waters of the lakes in relation to the mouth of the Rio Martino towards the sea, had to be useful, as well as to prevent the water level from rising more than necessary, to manage

\footnotetext{
67 Piccarreta 1977, 15.

68 Frutaz 1972, II, tab. 177.

69 Elter 1884, 73.

70 See the first specific contribution on the subject: Lugli 1928, 41-45.

71 Brandizzi Vittucci 1998. Already discussed in Ebanista 2017, 31-33.

72 Elter 1884, 73; Eph. Epigr. VIII, I 650; Ebanista 2011, 49-50; AE 2011, 225; Ebanista 2017,53-54; Chioff, 2018, 56, n. 28.
} 
the fish farming ${ }^{73}$ of the lakes, surely in use. In this regard, reference is made to the fragment of inscribed dolium: L(iquaminis) quindecim ur(nae) discovered between Pontinia and Sabaudia, therefore behind the lakes, which attests the production of garum in coastal pon$\mathrm{ds}^{74}$. The fish farming was an use established in Italy after the Hannibal war and became the expression of a new category of rich people. In particular for the Pontine Plain, the coastal ponds, characterized by calm and brackish waters, fed by fresh water from inland waterways, were the ideal place for fish farming. Several fish species were in fact attracted in these brackish basins from the continuous water exchange with rivers and streams that merged and mitigated them the waters. Since the Roman age the technique of catching fish during the continuous migration of fish from basins to the open sea was developed ${ }^{75}$.

AFCB Archivio fotografico del Consorzio di Bonifica dell'Agro Pontino

AFN Aerofototeca Nazionale

ASC Archivio Storico Capitolino

ASL Archivio di Stato di Latina

CIL Corpus Inscriptionum Latinarum, consilio et auctoritate Academiael itterarum regiae Borussicaeeditum, Berolini 1863 -

CLE Carmina Latina epigraphica, 1 -3, Leipzig 1894 -1930

Eph. Epigr. Ephemeris epigraphica. Corporis inscriptionum Latinarum supplementum, edita iussu Instituti archaeologici Romani, Berolini 1872 - 1913

ILS Dessau, Hermann. 1892-1916. Inscriptiones latinae selectae, Berlin: Berolini

\section{Bibliography}

Alessandri, L. 2007. L'occupazione costiera protostorica nel Lazio centromeridionale (BAR 1592), Oxford: BAR.

Angle, M., Zarattini, A. 1987. "L'insediamento protostorico di Casale Nuovo", in ArchLaz 8 (QuadAEI 14), 250-252

Angle, M., Caneva, C., Conti, A.M., Dottarelli, M., Gianni, A., Giardino, C., Persiani, C. 1992. "Casale Nuovo (LT) e la tarda età del bronzo nel Lazio Meridionale", in Atti del $3^{\circ}$ Convegno di Studi. Un millennio di relazioni fra la Sardegna e i paesi del Mediterraneo, Cagliari: Edizioni della Torre, 265-303.

73 Giacopini et al. 1994.

74 Ebanista 2017, 22-23 and cited bibliography.

75 Conta 1972. 
Arnoldus-Huyzendveld, A., Perotto, C., Sarandrea, P. 2009. I suoli della provincia di Latina. Carta, database e applicazioni, Roma: Gangemi Editore.

Belardelli, C., Pascucci, P. 1996. Repertorio dei siti protostorici del Lazio. Province di Rieti e di Latina (Consiglio d'Europa Patrimonio archeologico), Roma: Nova Tiporom.

Boni, C., Bono, P., Calderoni, G., Lombardi, S., Turi, B. 1980. "Indagine idrogeologica e geochimica sui rapporti tra ciclo carsico e circuito idrotermale nella Pianura Pontina", in Geologia Applicata e Idrogeologia 15, 204-247.

Brandizzi Vittucci, P. 1998. "Considerazioni sulla Via Severiana e sulla Tabula Peutingeriana”, in MEFRA 110 (1998-2), 929-993.

Caciorgna, M.T. 2008. "Genova e Terracina nel XIV secolo: caratteri e forme di un dominio tirrenico", in Mazzon, A. 2008. Raccolta di studi offerti scritti a Isa Lori Sanfilippo, Roma: Istituto Storico Italiano per il Medio Evo, 69-87.

Caciorgna, M.T. 2016. "L'assetto idrico del territorio pontino", in Vitolo, G. (edited by). 2016. Città, spazi pubblici e servizi sociali nel mezzogiorno medievale (Società Napoletana di Storia Patria. Centro interuniversitario per la storia delle città campane nel medioevo. Quaderni 8), Battipaglia: Laveglia\&Carlone.

Cancellieri, M. 1990. "Il territorio pontino e la via Appia", in ArchLaz 10.1 (QuadAEI 18), 123-125.

Cardarelli, A., Di Gennaro, F., Guidi, A., Pacciarelli, M. 1980. "Le ricerche di topografia protostorica nel Lazio. Il bronzo finale in Italia", in Archeologia Materiali e Problemi I, 91-103.

Cerreti, C. 2003. "Il quadro geografico del Lazio come base dell'antropizzazione", in Sommella P. (edited by). 2003. Atlante del Lazio, Roma: Istituto Nazionale di Studi Romani, $1-26$.

Chioffi, L. 2018. Antium. Noterelle Antiatinae, Anzio: Tipografia Marina

Cipolla, C. 2013. Il sogno di Garibaldi. Oltre Terracina, contro i Borboni, Milano: Franco Angeli.

Conta, G. D., 1972. "Note sulle peschiere marittime del mondo romano", in Schmiedt, G., Il livello antico del Mar Tirreno, Firenze: Olschki, 215-221.

De la Blanchère, M. R. 1884. Terracine, essai d'histoire locale, Parigi: Ernest Thorin Èditeur 1884

Di Filippo, M., Toro, B. 1980. "Analisi gravimetrica delle strutture geologiche del Lazio Meridionale", in Geologica Romana XIX, pp. 285-294

Ebanista, L. 2011. "Insediamenti costieri nell'area di Fogliano" in Orizzonti: rassegna di archeologia XII, 123-131.

Ebanista, L. 2017. Ager Pomptinus I, Forma Italiae 46. Roma: Quasar.

Ebanista, L. 2020. "Osservazioni sul 'faro' del porto di Astura", in Atlante tematico di Topografia Antica 30, 241-250. 
Egidi, R. 1980. "Una statio romana sulla Via Severiana ad TurresAlbas", in ArchLaz 3 (QuadAEI 4), 123-125.

Elter, A. 1884. “Antichità pontine", in Bullinst 1884, 56-79

Frutaz, A.P. 1972. Le carte del Lazio I-III, Roma: A. Staderini S.p.A.

Giacopini, L., Marchesini B.B., Rustico, L. 1994. L'itticoltura nell'antichità, Roma: ENEL.

Giardino, C. 2006. "Il villaggio dell'età del Bronzo di Casale Nuovo: lavorazione di rame e piombo in un sito con ceramica di tipo egeo", in Astura, Satricum, Pometia, un itinerario alle origini di Latina - Atti del Convegno Latina 27 marzo 2004, Latina: Comune di Latina, $25-48$

Gnade, M. (edited by). 2017. Satricum. Trenta anni di scavi olandesi - Catalogo della mostra Le Ferriere, Latina 26 ottobre 2007 - 29 febbraio 2008, Amsterdam: Amsterdams Archeologisch Centrum.

Guidi, A. 1989. "L'età dei metalli nella Valle Pontina", in Atti del Convegno Incontro con l'archeologia. Sabaudia 1989. Sabaudia: Parco Nazionale del Circeo, pp. 25-29.

Jaia, A.M. 2017. "Appunti per una storia economica della costa laziale tra Ostia e il Circeo. Approdi e contesti produttivi”, in Scienze dell'Antichità 23, 209-221.

La Rosa, M. 1984a. "L'insieme litico pontiniano del podere La Rosa (Borgo S. Maria - Latina)", in Studi per l'ecologia del Quaternario 6, 1984, 9-27.

La Rosa, M. 1984b. "Introduzione allo studio del musteriano pontiniano: la stazione litica del podere La Rosa", in Preistoria d'Italia alla luce delle ultime scoperte (Atti del IV convegno nazionale di preistoria e protostoria - Pescia 8-9 dicembre 1984), Pescia 1984, 221-226.

La Rosa, M. 2006. "Alla scoperta dei primi abitanti dell'agro pontino. Nuovi ritrovamenti nella valle del fiume Astura", in Astura, Satricum, Pometia, un itinerario alle origini di Latina - Atti del Convegno 27 marzo 2004, Latina: Centro stampe del Comune di Latina, 10-24.

La Rosa, M., Mazza, P., Rustioni, M., Vianello, F. 1992. "Agro Pontino (prov. di Latina e Roma)", in RscPreist 42, 1-2, 1989-90, 356-359

La Rosa, M., Milliken, S., Peretto, C. 1996. "Il sito del Paleolitico inferiore di Quarto delle Cinfonare (LT): Ambiente paleografico e sfruttamento della selce", in Atti dell'XI Congresso degli Antropologi Italiani, Isernia 1995, Forlì: A.B.A.C.O., 143-154

Le Pera Buranelli, S. 1994. "Il lago di Fogliano", in Il Lazio di Thomas Ashby 1891-1930, Roma: Palombi stampa, 173-175

Ligato, D. (edited by). 2003. Atlante delle opere di sistemazione fluviale, Roma: APAT.

Lugli, G. 1928.Circeii, Forma Italiae2, Roma: Danesi.

Moroni, G. 1854. Dizionario di erudizione storico-ecclesiastica, LXV, Venezia: Tipografia Emiliana.

Orsolini Cencelli, V. 1935. "La bonifica e la trasformazione fondiaria dell'agro pontino", in $L a$ bonifica delle paludi pontine 1935-XIV, Roma: Leonardo Da Vinci, 231-257 
Peretto, C., La Rosa, M., Liboni, A., Milliken, S., Sozzi, M., Zarattini, A. 1997. "Le gisement de Quarto delle Cinfonare dans le cadre du Paléolithique inférieur de l'Italieouest-centrale", in L'Anthropologie, 101(4), 597-615

Piccarreta, F. 1977, Astura, Forma Italiae 12. Firenze: De Luca Editore.

Quilici, L. 1998. "Nero Claudius Caesar Kosmocrator", in I Culti della Campania Antica. Atti del Convegno internazionale di studi in ricordo di Nazarena Valenza Mele (Napoli, 15-17 maggio 1995), Roma: G. Bretschneider, 200-212.

Tol, G. 2012. A Fragmented History A methodological and artefactual approach to the study of ancient settlement in the territories of Satricum and Antium, Groningen: Barkhuis\& Groningen University Library.

Traina, G. 1988. Paludi e bonifiche del mondo antico. Roma: L'Erma di Bretschneider.

Zei, M. 1988. "Siti all'aperto musteriani nel Lazio costiero centro-meridionale", in Bietti, A., Manzi, G., Zei, M. (edited by), Il territorio pontino nella preistoria (Quad. del CEPIG 2122), 83-94. 